\title{
The Composition of Undergrowth Vegetation in Forest Area with the Special Purpose of Gunung Bromo, Karangayar, Central Java, Indonesia
}

\author{
Abdul Ghaffar Amiruddin Zaki ${ }^{1}$, Yus Andhini Bhekti Pertiwi ${ }^{2, *}$, Malihatun Nufus ${ }^{2}$, Amalia Tetrani Sakya ${ }^{1}$ \\ ${ }^{1}$ Agrotechnology Program, Faculty of Agriculture, Universitas Sebelas Maret. J1. Ir. Sutami No. 36A, Kentingan, Jebres, Surakarta \\ 57126, Central Java, Indonesia \\ ${ }^{2}$ Forest Management Program, Faculty of Agriculture, Universitas Sebelas Maret. Jl. Ir. Sutami No. 36A, Kentingan, Jebres, \\ Surakarta 57126, Central Java, Indonesia \\ * Corresponding Author. E-mail address: yus_andhini@staff.uns.ac.id
}

\section{ARTICLE HISTORY:}

Received: 31 October 2021

Peer review completed: 6 January 2022

Received in revised form: 12 January 2022

Accepted: 24 January 2022

\section{KEYWORDS:}

Important value index KHDTK of Gunung Bromo Species composition Species diversity Undergrowth vegetation

(C) 2022 The Author(s). Published by Department of Forestry, Faculty of Agriculture, University of Lampung in collaboration with Indonesia Network for Agroforestry Education (INAFE). This is an open access article under the CC BY-NC license:

https://creativecommons.org/licenses/by$\mathrm{nc} / 4.0 \%$

\begin{abstract}
Data on the biodiversity is essential to support the Forest Area with the Special Purpose (KHDTK) of Gunung Bromo as an educational forest and training center. This study aimed to obtain basic information on undergrowth vegetation composition under pine stands. Furthermore, the important value index $(I V I)$, species diversity index $\left(H^{\prime}\right)$, species richness index $(R)$, and evenness index $(E)$ were determined. The data was systematically obtained by marking 35 plots of $2 \mathrm{~m} \times 2 \mathrm{~m}$. The distance between plots was $100 \mathrm{~m}$. The results showed that the undergrowth vegetation consisted of 39 species from 26 families. The habitus of undergrowth vegetation was herb (15 species), shrub (14 species), liana (3 species), fern (6 species), and palm (1 species). Eragrostis tenerum was the dominant species with an IVI of 58.84\%). Centrosema pubescens showed an IVI of $18.38 \%$, while the other species showed less than $10 \%$. Furthermore, $H^{\prime}$ was classified as moderate (2.35), $R$ was classified as moderate (4.69), and $E$ was classified as uneven (0.64). This condition indicated that the undergrowth species that grew in KHDTK of Gunung Bromo was limited and uneven. It was considered due to inhibiting factors such as allelopathy in pine leaf litter and low light intensity. Undergrowth species that grow in KHDTK of Gunung Bromo showed several potential utilizations, such as medicinal plants (30 species), ornamental plants ( 9 species), food sources ( 5 species), forage (4 species), culture and crafts (4 species), and conservation ( 3 species).
\end{abstract}

\section{Introduction}

Forest Area with Special Purpose or Kawasan Hutan Dengan Tujuan Khusus (KHDTK) of Gunung Bromo is a forest area that Universitas Sebelas Maret (UNS) currently managed based on the Decree of the Minister of Environment and Forestry SK.177/MENLHK/SETJEN/PLS./4/2018. The primary purposes of this forest area are for research and education. Before being handed over to UNS, KHDTK of Gunung Bromo was a limited production forest managed by a state-owned forestry enterprise (Perum Perhutani). The main forest product was pine (Pinus merkusii) resin at that time. Thus, pine was the dominant tree species in KHDTK of Gunung Bromo. The covering area of the pine stand was 100.3 ha or equivalent to $\pm 80 \%$ of the total area. 
Studies on vegetation analysis and stand biomass in KHDTK of Gunung Bromo had been reported (Ikhsan et al. 2021; Nufus et al. 2020). Nufus et al. (2020) reported that pine's volume and stand potency were $156.7 \mathrm{~m}^{3} /$ ha and 202 trees/ha. In addition, Ikhsan et al. (2021) reported that the total biomass and carbon stock in pine-mahogany mixture stands were 45.90 ton/ha and 68.57 ton $\mathrm{C} /$ ha. It is necessary to conduct an inventory of undergrowth vegetation because undergrowth vegetation has ecological (environmental services) and economic functions. Several studies have been reported that undergrowth vegetation has the potency to be used as food, medicine, forage, and botanical insecticides (Abdiyani 2008; Hadi et al. 2016). Djufri (2003) suggested that the presence of undergrowth vegetation could be used as an environmental indicator. In addition, undergrowth vegetation has an essential role in the forest ecosystem and microclimate (Hilwan et al. 2013). The presence of undergrowth vegetation on the forest floor act as a barrier against rainwater and surface runoff (Abdiyani 2008; Hilwan et al. 2013). Furthermore, the undergrowth litter increases the forest soil nutrients (Sabaruddin et al. 2009; Hilwan et al. 2013). Moreover, data on biodiversity is essential to support KHDTK of Gunung Bromo as the location for forestry education and training center. Thus, the composition and diversity of undergrowth vegetation must be considered.

Several studies have been conducted on undergrowth vegetation inventories in various plantation forests, such as in pine (Destaranti et al. 2017; Djufri 2003; Kunarso and Azwar 2013; Purnomo et al. 2018; Yusra et al. 2017), Swietenia macrophylla, Peronema canescens, Schima walichii (Kunarso and Azwar 2013), Casuarina equisetifolia (Atmanto et al. 2017), Agathis alba (Purnomo et al. 2018), Enterolobium cyclocarpum, and Samanea saman (Hilwan et al. 2013). The results of the previous research showed that species, numbers, habitus, and distribution of undergrowth were diverse. Thus, it indicated that the stand species, shade, site quality, altitude, and environmental condition create a unique and specific microclimate. Therefore, studying undergrowth vegetation is necessary.

The present study aimed to obtain basic information on the composition of undergrowth vegetation in KHDTK of Gunung Bromo. Therefore, the important value index, species diversity index, species richness index, and species evenness index of undergrowth were analyzed. In addition, the potential utilization of undergrowth was described. Therefore, data on the composition of undergrowth vegetation could support the management of KHDTK of Gunung Bromo.

\section{Materials and Methods}

\subsection{Study Area}

The study was conducted in KHDTK of Gunung Bromo, Karanganyar, Central Java ( $7^{\circ} 34^{\prime}$ $21.93 "-7^{\circ} 35^{\prime} 38.90^{\prime \prime} \mathrm{S}$ and $110^{\circ} 59^{\prime} 40.39^{\prime \prime}-111^{\circ} 0^{\prime} 49.36^{\prime \prime} \mathrm{E}$ ), with an altitude of 244-362 masl (Fig. 1). The total area of KHDTK of Gunung Bromo is 126.291 ha. The study was conducted on the mixed stands of pine (Pinus merkusii) and mahogany (Swietenia macrophylla) that were planted in the range of 1991-2007. The data was collected from May to July 2019.

The average air temperature, humidity, and light intensity at KHDTK of Gunung Bromo were $31.8^{\circ} \mathrm{C}, 71.24 \%$, and $814 \mathrm{Cd}$, respectively. Meanwhile, the average annual rainfall was about $1,966 \mathrm{~mm} /$ year. The climate in KHDTK of Gunung Bromo is classified as type $\mathrm{C}$ with an average dry-wet month ratio of $37.5 \%$ with eight wet months, three dry months, and one humid month. In 
addition, the soil temperature, humidity, and $\mathrm{pH}$ were $26.8-30.9^{\circ} \mathrm{C}, 1.4-7.5 \%$, and $6.4-6.9$, respectively (Ikhsan et al. 2021).

\subsection{Methods}

The plots used in the present study were determined by systematic sampling with a random start. The sampling intensity was $0.05 \%$. The method and sampling intensity were determined by considering the condition of KHDTK of Gunung Bromo. The forest area is a plantation forest consisting mainly of pine; therefore, the stand condition was uniform in all forest areas. The first plot was randomly determined under the pine stand, and the following plots were systematically set by $100 \mathrm{~m}$ in the distance. In total, 35 square plots were set up under the pine-mahogany mixture stands. The plot size was $2 \mathrm{~m}$ x 2 m (Destaranti et al. 2017; Indriyanto 2017; Kusmana 2017; Purnomo et al. 2018; Syahbudin et al. 2020). The number, species name, and habit were collected. The herbarium samples and photos were taken for undersigned plants and then identified at Dendrology Laboratory, Faculty of Forestry, Gadjah Mada University.

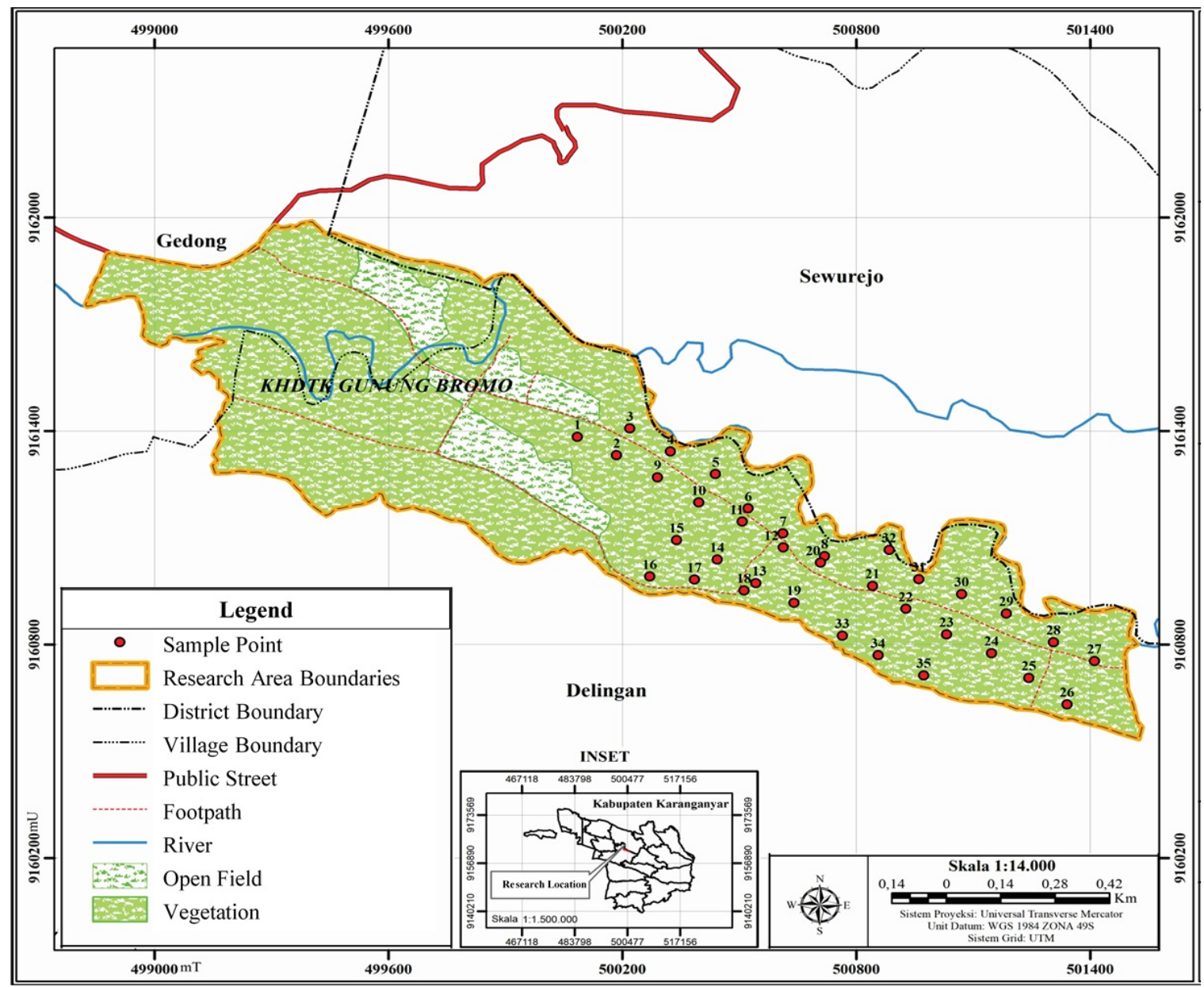

Fig. 1. Map showing the study area and plots observed in KHDTK of Gunung Bromo, Karanganyar, Central Java.

\subsection{Data Analysis}

The research data obtained from the plots were analyzed. Each species was analyzed using the importance value index. Furthermore, the diversity index, evenness index, and species richness index were also calculated. 


\subsubsection{Importance value index}

The role of each undergrowth species on the ecosystem was analyzed by the important value index (IVI) (Purnomo et al. 2018). IVI was obtained by summarizing the density and frequency for each species by using the following equations (Destaranti et al. 2017; Purnomo et al. 2018; Syahbudin et al. 2020).

Density $(D)=\frac{\text { Pindividual }}{\text { Plot area }}$

Relative density $(R D)=\frac{\text { Species density }}{\text { The total density of all species }} \times 100 \%$

Frequency $(F)=\frac{\text { Eplots in which species occur }}{\sum \text { plot studied }}$

Relative frequency $(R F)=\frac{\text { Frequency of species }}{\text { The total frequency of all species }} \times 100 \%$

$I V I=R D+R F$

\subsubsection{Diversity index}

Diversity Index $\left(H^{\prime}\right)$ was used to determine the diversity level of undergrowth species. The undergrowth diversity was analyzed by Shannon-Wiener Index (Indriyanto 2017) using the following equations:

$$
\begin{aligned}
& H^{\prime}=-\sum_{i} p_{i} \ln p_{i} \\
& p_{i}=\frac{n i}{N}
\end{aligned}
$$

where $p_{i}$ is the comparison of the number of individual species with all species, $n_{i}$ is the number of individual species-i, and $N$ is the total individuals of all species. The criteria of $H^{\prime}$ are as follows: $H^{\prime} \leq 1=$ low diversity, $1<H^{\prime}<3=$ medium diversity, $H^{\prime} \geq 3=$ high diversity.

\subsubsection{Evenness index}

Evenness index $(E)$ shows how the individuals in a community are evenly distributed among the different species. The evenness index was calculated using equation 8 (Indriyanto 2017).

$$
E=\frac{H^{\prime}}{\ln (S)}
$$

where $S$ is the total species. The criteria of $E$ are as follow: $\mathrm{E} \leq 0.4=$ low, $0.4<\mathrm{E}<0.6=$ moderate, and $\mathrm{E} \geq 0.6$ = high.

\subsubsection{Species richness index}

Species richness index $(R)$ is simply a measure of biodiversity. It is the measure of the total number of different species in a community or given area. The undergrowth species richness index was determined by the Margalef index (Indriyanto 2017) as follows:

$$
R=\frac{S-1}{\ln N}
$$

where $S$ is the number of species and $N$ is the number of individual species. The criteria of $R$ are as follows: $R \leq 3.5=$ low, $3.5<R<5=$ moderate, and $R \geq 5=$ high. 


\section{Results and Discussion}

\subsection{Composition of Undergrowth Vegetation}

Table 1 shows the composition of undergrowth vegetation under the pine stand in KHDTK of Gunung Bromo.

Table 1. Composition of undergrowth vegetation in KHDTK of Gunung Bromo

\begin{tabular}{|c|c|c|c|}
\hline No & Species & Family & Habitus \\
\hline 1 & Artabotrys hexapetalus & Annonaceae & Shrub \\
\hline 2 & Rauvolfia serpentina & Apocynaceae & Shrub \\
\hline 3 & Philodendron hederaceum & Araceae & Herb \\
\hline 4 & Caryota mitis & Arecaceae & Palm \\
\hline 5 & Eupatorium odoratum & Asteraceae & Shrub \\
\hline 6 & Cosmos caudatus & Asteraceae & Herb \\
\hline 7 & Melanthera biflora & Asteraceae & Herb \\
\hline 8 & Mikania micrantha & Asteraceae & Herb \\
\hline 9 & Sarcandra glabra & Cloranthaceae & Herb \\
\hline 10 & Costus spicatus & Costaceae . & Herb \\
\hline 11 & Vitis pentaphylla & Cucurbitaceae & Herb \\
\hline 12 & Cyperus rotundus & Cyperaceae & Herb \\
\hline 13 & Tetracera scandens & Dilleniaceae & Liana \\
\hline 14 & Dioscorea alata & Dioscoreaceae & Herb \\
\hline 15 & Mimosa pudica & Fabaceae & Shrub \\
\hline 16 & Centrosema pubescens & Fabaceae & Herb \\
\hline 17 & Flemingia macrophylla & Fabaceae & Shrub \\
\hline 18 & Lygodium flexosum & Lygodiaceae & Fern \\
\hline 19 & Lygodium palmatum & Lygodiaceae & Fern \\
\hline 20 & Urena lobata & Malvaceae & Shrub \\
\hline 21 & Clidemia hirta & Melastomataceae & Shrub \\
\hline 22 & Melastoma affine & Melastomataceae & Shrub \\
\hline 23 & Nephrolepis cordifolia & Neprolepidaceae & Fern \\
\hline 24 & Bougainvillea sp. & Nyctaginaceae & Shrub \\
\hline 25 & Bridelia stipularis & Phyllantaceae & Liana \\
\hline 26 & Sauropus androgynus & Phyllantaceae & Shrub \\
\hline 27 & Peperomia pellucida & Piperaceae & Herb \\
\hline 28 & Eragrostis tenerum & Poaceae & Herb \\
\hline 29 & Ischaemum timorense & Poaceae & Herb \\
\hline 30 & Pteris latipinna & Pteridaceae & Fern \\
\hline 31 & Adiantum pidatum & Pteridaceae & Fern \\
\hline 32 & Pteris ensiformis & Pteridaceae & Fern \\
\hline 33 & Ziziphus elegans & Rhamnaceae & Shrub \\
\hline 34 & Chassalia curviflora & Rubiaceae & Shrub \\
\hline 35 & Ixora javanica & Rubiaceae & Shrub \\
\hline 36 & Meyna spinosa & Rubiaceae & Shrub \\
\hline 37 & Tacca palmata & Taccaceae & Herb \\
\hline 38 & Cayratia pedata & Vitaceae & Liana \\
\hline 39 & Zingiber officinale & Zingiberaceae & Herb \\
\hline
\end{tabular}

The undergrowth consisted of 39 species from 26 families. Based on their habitus, the undergrowth is classified as herbs (15 species), shrubs (14 species), lianas (3 types), ferns (6 species), and palms (1 species). Similar research has been conducted in the other pine forest area (Destaranti et al. 2017; Djufri 2003; Kunarso and Azwar 2013; Purnomo et al. 2018; Yusra et al. 2017). In the pine forest owned by PT. Inhutani IV Aceh Besar, there was 66 species undergrowth 
(Djufri 2003). Destaranti et al. (2017) reported that 32 and 19 species undergrowth under pine stands in RPH Kalirajut and RPH Baturaden Tengah. Yusra et al. (2017) reported that 25 species undergrowth were identified in Tahura Pocut Meurah Intan. The differences in undergrowth composition in various pine forest areas as mentioned above can be understood as a result of the combination of main vegetation types, canopy cover, microclimate, soil quality, and topographic conditions (slope and height).

The number, density, relative density, frequency, relative frequency, and IVI of each undergrowth species are shown in Table 2. Eragrostis tenerum was dominant species (IVI $58.84 \%$ ). The high $I V I$ indicated that the species could control and show high adaptability rather than other species (Lubis 2008; Nurkhotimah et al. 2017; Siappa et al. 2016). Abdiyani et al. (2008) also emphasized that the dominant species is essential, especially in terms of environmental conditions and the existence of other species. In addition, several dominant species with high adaptability are invasive (Solfiyeni et al. 2016). This trait makes plants dominate an area and suppress the growth of other plants around them through growth competition (Tjitrosoedirdjo et al. 2016).

Eragrostis tenerum belongs to Poaceae. Several researchers also reported that the dominant undergrowth species grown in pine stands belonged to Poaceae (Destaranti et al. 2017; Djufri 2003; Kunarso and Azwar 2013; Yusra et al. 2007). Djufri (2003) reported that Oplismenus burmanii showed IVI of 61.26\% in pine plantations in Aceh Besar. In addition, Yusra et al. (2007) reported that Panicum repens (IVI 31.57\%) was the most common species found under pine stands in Tahura Pocut Meurah Intan, Aceh Besar. Destaranti et al. (2017) reported that 9 species of undergrowth belonging to Poaceae grew under pine stands in Forest Management Unit (KPH) Kalirajut. Kunarso and Azwar (2013) reported that Cyrtococcum accrescens (IVI 56.18\%) was the dominant species that grows under pine stand in KHDTK Benakat, South Sumatra. Poaceae lived in various habitats due to their high adaptability (Destaranti et al. 2017). The pine canopy was relatively light; therefore, the forest floor was quite suitable, especially in light intensity. In addition, the Poaceae that became dominant might be due to their capability to cope with pine allelopathy.

Centrosema pubescens showed an IVI of $18.38 \%$. C. pubescens are long-lived legumes that grow twisted and spread, resistant to dry conditions, and can live in the shade and inundated land (Indriani et al. 2019). Indriani et al. (2019) also reported that forage production and quality were higher by planting $C$. pubescens in the same location. In addition, as a legume, C. pubescens can fix nitrogen from the air, and the litter act as a nutrient source. Therefore, the $C$. pubescens growth has a beneficial impact on the main forest stand.

The other species shows an IVI of less than 10\%. The low IVI indicated that the species has poor adaptation to local environmental factors (Siappa et al. 2016). This condition was presumably because pine leaf litter mostly covered the forest floor. The pine leaf litter is difficult to decompose and contains high allelopathy. Allelopathy often has inhibitory or contributory effects on seed germination and plant growth (Rice 1984). 
Table 2. Density, relative density, frequency, relative frequency, and importance value index of undergrowth vegetation in KHDTK of Gunung Bromo

\begin{tabular}{|c|c|c|c|c|c|c|}
\hline No & Species & $D$ & $R D(\%)$ & $F$ & $R F(\%)$ & $I V I(\%)$ \\
\hline 1 & Artabotrys hexapetalus & 0.25 & 0.03 & 0.03 & 0.35 & 0.38 \\
\hline 2 & Rauvolfia serpentina & 13.50 & 1.64 & 0.17 & 2.08 & 3.72 \\
\hline 3 & Philodendron hederaceum & 2.50 & 0.30 & 0.14 & 1.73 & 2.03 \\
\hline 4 & Caryota mitis & 3.75 & 0.46 & 0.11 & 1.38 & 1.84 \\
\hline 5 & Eupatorium odoratum & 23.00 & 2.79 & 0.31 & 3.81 & 6.60 \\
\hline 6 & Cosmos caudatus & 9.75 & 1.18 & 0.23 & 2.77 & 3.95 \\
\hline 7 & Melanthera biflora & 12.00 & 1.46 & 0.03 & 0.35 & 1.80 \\
\hline 8 & Mikania micrantha & 6.00 & 0.73 & 0.06 & 0.69 & 1.42 \\
\hline 9 & Sarcandra glabra & 8.75 & 1.06 & 0.17 & 2.08 & 3.14 \\
\hline 10 & Costus spicatus & 5.00 & 0.61 & 0.06 & 0.69 & 1.30 \\
\hline 11 & Vitis pentaphylla & 13.25 & 1.61 & 0.40 & 4.84 & 6.45 \\
\hline 12 & Cyperus rotundus & 27.00 & 3.28 & 0.17 & 2.08 & 5.36 \\
\hline 13 & Tetracera scandens & 12.50 & 1.52 & 0.17 & 2.08 & 3.59 \\
\hline 14 & Dioscorea alata & 29.25 & 3.55 & 0.49 & 5.88 & 9.44 \\
\hline 15 & Mimosa pudica & 5.00 & 0.61 & 0.06 & 0.69 & 1.30 \\
\hline 16 & Centrosema pubescens & 62.25 & 7.56 & 0.89 & 10.73 & 18.29 \\
\hline 17 & Flemingia macrophylla & 6.00 & 0.73 & 0.06 & 0.69 & 1.42 \\
\hline 18 & Lygodium flexosum & 19.50 & 0.91 & 0.23 & 2.77 & 3.68 \\
\hline 19 & Lygodium palmatum & 5.75 & 0.67 & 0.11 & 2.77 & 3.44 \\
\hline 20 & Urena lobata & 21.50 & 0.70 & 0.34 & 1.38 & 2.08 \\
\hline 21 & Clidemia hirta & 3.25 & 2.61 & 0.09 & 4.15 & 6.76 \\
\hline 22 & Melastoma affine & 2.50 & 0.39 & 0.06 & 1.04 & 1.43 \\
\hline 23 & Nephrolepis cordifolia & 0.25 & 2.37 & 0.03 & 2.77 & 5.14 \\
\hline 24 & Bougainvillea sp. & 4.50 & 0.30 & 0.29 & 0.69 & 1.00 \\
\hline 25 & Bridelia stipularis & 1.00 & 0.03 & 0.06 & 0.35 & 0.38 \\
\hline 26 & Sauropus androgynus & 391.50 & 0.55 & 0.91 & 3.46 & 4.01 \\
\hline 27 & Peperomia pellucida & 32.25 & 0.12 & 0.40 & 0.69 & 0.81 \\
\hline 28 & Eragrostis tenerum & 29.25 & 47.56 & 0.40 & 11.07 & 58.63 \\
\hline 29 & Ischaemum timorense & 0.50 & 3.92 & 0.03 & 4.84 & 8.76 \\
\hline 30 & Pteris latipinna & 7.50 & 3.55 & 0.23 & 4.84 & 8.40 \\
\hline 31 & Adiantum pidatum & 21.50 & 0.06 & 0.23 & 0.35 & 0.41 \\
\hline 32 & Pteris ensiformis & 5.50 & 2.61 & 0.23 & 2.77 & 5.38 \\
\hline 33 & Ziziphus elegans & 1.25 & 0.15 & 0.09 & 1.04 & 1.19 \\
\hline 34 & Chassalia curviflora & 7.75 & 0.94 & 0.20 & 2.42 & 3.36 \\
\hline 35 & Ixora javanica & 7.75 & 0.94 & 0.14 & 1.73 & 2.67 \\
\hline 36 & Meyna spinosa & 0.50 & 0.06 & 0.03 & 0.35 & 0.41 \\
\hline 37 & Tacca palmata & 3.75 & 0.46 & 0.11 & 1.38 & 1.84 \\
\hline 38 & Cayratia pedata & 9.00 & 1.09 & 0.20 & 2.42 & 3.52 \\
\hline \multirow[t]{2}{*}{39} & Zingiber officinale & 7.25 & 0.88 & 0.31 & 3.81 & 4.69 \\
\hline & tal & 823.25 & 100.00 & 8.26 & 100.00 & 200.00 \\
\hline
\end{tabular}

Notes: $\Sigma=$ number of individual, $D=$ density, $R D=$ relative density, $F=$ frequency; $R F=$ relative frequency, $I V I=$ important value index.

The species diversity index $\left(H^{\prime}\right)$ was classified as moderate (Table 3). Higher diversity index $\left(H^{\prime}>3\right)$ indicated that the vegetation community was stable (Wirakusumah 2003). Thus, the undergrowth vegetation in KHDTK of Gunung Bromo was heading towards a more stable condition. The species richness index $(R)$ was also classified as moderate. This condition was presumably due to some limiting growth factors, for example, environmental factors such as altitude, soil conditions, temperature, light intensity, and rainfall (Siappa et al. 2016). In the present study, allelopathy in pine leaf litter and light intensity were suspected as the main limiting factors. 
In addition, the evenness index $(E)$ was considered uneven, indicating that the distribution of individual species was uneven.

Table 3. Species diversity index, species richness index, and evenness index of undergrowth vegetation in KHDTK of Gunung Bromo

\begin{tabular}{lcc}
\hline \multicolumn{1}{c}{ Index } & Score & Category \\
\hline Species Diversity Index (H') & 2.35 & Moderate \\
Species Richness Index (R) & 4.69 & Moderate \\
Evenness Index (E) & 0.64 & Uneven \\
\hline
\end{tabular}

\subsection{Potential Utilization of Undergrowth Vegetation}

Table 4 shows the potential utilization of undergrowth vegetation in KHDTK of Gunung Bromo based on various references. Several species might show several potential utilizations. The greatest potential utilization of undergrowth was as medicinal plants (30 species), such as $E$. oderatum, C. caudatus, C. spicatus, C. rotundus, $M$. pudica, and P. pellucida. These herbs have potential utilization for minor diseases (colds, stomachache, diarrhea, and cough) and chronic diseases (diabetes, lung, liver, and cancer).

Table 4. Potential utilization of undergrowth vegetation in KHDTK of Gunung Bromo

\begin{tabular}{|c|c|c|}
\hline No & Species & Potential utilization \\
\hline 1 & Artabotrys hexapetalus & Medicinal plants produce aromatherapy oil ${ }^{1}$ \\
\hline 2 & Rauvolfia serpentina & Medicines to prevent fever, sedatives, hypertension ${ }^{2}$ \\
\hline 3 & $\begin{array}{l}\text { Philodendron } \\
\text { hederaceum }\end{array}$ & Ornamental plant ${ }^{3}$ \\
\hline 4 & Caryota mitis & Decorative plant, leaves contain antioxidants ${ }^{4}$ \\
\hline 5 & Eupatorium odoratum & $\begin{array}{l}\text { Gout, rheumatism, antimicrobial, anti-hepatitis, colds, headaches, and } \\
\text { fever }^{5}\end{array}$ \\
\hline 6 & Cosmos caudatus & $\begin{array}{l}\text { Food }{ }^{6} \text {, ornamental plants }{ }^{7} \text {, antioxidants and decreased glucose levels } \\
\text { in blood }\end{array}$ \\
\hline 7 & Melanthera biflora & Medicinal plants 9 \\
\hline 8 & Mikania micrantha & Medicinal plants $^{10,39}$, bioherbiside $^{11}$ \\
\hline 9 & Sarcandra glabra & Medicinal plants ${ }^{12}$ \\
\hline 10 & Costus spicatus & Medicinal plants $^{12,13,39}$ \\
\hline 11 & Vitis pentaphylla & $\begin{array}{l}\text { Medicinal plants for diabetes mellitus, detoxification, cough } \\
\text { medicine, anti-inflammatory, chronic bronchitis }{ }^{14}\end{array}$ \\
\hline 12 & Cyperus rotundus & $\begin{array}{l}\text { Stomach pain medication, worm medicine, facilitate urination, } \\
\text { hormonal cycles, ulcers, wounds, ulcers, nausea }{ }^{15}\end{array}$ \\
\hline 13 & Tetracera scandens & Medicinal plants ${ }^{16}$ \\
\hline 14 & Dioscorea alata & Food $^{17}$ \\
\hline 15 & Mimosa pudica & $\begin{array}{l}\text { Asthma medication, worm medicine, kidney stone medicine, } \\
\text { dysentery, hemorrhoids, jaundice, leprosy }{ }^{18,39}\end{array}$ \\
\hline 16 & Centrosema pubescens & Forage $^{19}$ \\
\hline 17 & Flemingia macrophylla & $\begin{array}{l}\text { Rheumatism drugs, joint disorders, and nephritis (root). Cosmetics, } \\
\text { deworming, cough and cold (pods), rheumatism and inflammation } \\
\text { (stems) } \text { ) }^{18}\end{array}$ \\
\hline 18 & Lygodium flexosum & Ornamental plants ${ }^{20}$ \\
\hline 19 & Lygodium palmatum & Foods, handicrafts, organic fertilizers, medicinal plants ${ }^{21}$ \\
\hline 20 & Urena lobata & $\begin{array}{l}\text { Medicines for param }{ }^{22} \text {, drugs for malaria, gonorrhea, rheumatism, } \\
\text { wounds, and fever }\end{array}$ \\
\hline
\end{tabular}




\begin{tabular}{|c|c|c|}
\hline No & Species & Potential utilization \\
\hline 21 & Clidemia hirta & Forage and ulcers medicine ${ }^{24,39}$ \\
\hline 22 & Melastoma affine & $\begin{array}{l}\text { Diarrhea medication, maintaining stamina, colitis, mouth sores, } \\
\text { seizures }^{25}\end{array}$ \\
\hline 23 & Nephrolepis cordifolia & Food, medicinal plants, ornamental plants ${ }^{26}$ \\
\hline 24 & Bougainvillea sp. & Medicinal plants, ornamental plants, traditional events ${ }^{27}$ \\
\hline 25 & Bridelia stipularis & $\begin{array}{l}\text { Medicinal plants, relieve cough, asthma, allergies, jaundice, malaria, } \\
\text { scabies, allergies, anemia, natural dyes }{ }^{28}\end{array}$ \\
\hline 26 & Sauropus androgynus & Food especially adequacy of breastfeeding, forage $\mathrm{e}^{27,39}$ \\
\hline 27 & Peperomia pellucida & Medicinal and ornamental plants ${ }^{27,39}$ \\
\hline 28 & Eragrostis tenerum & Forage $^{29}$ \\
\hline 29 & Ischaemum timorense & Forage, preventing environmental erosion ${ }^{30}$ \\
\hline 30 & Pteris latipinna & Ornamental plants ${ }^{31}$ \\
\hline 31 & Adiantum pidatum & Ornamental plants ${ }^{31}$ \\
\hline 32 & Pteris ensiformis & Food, handicrafts, organic fertilizers, medicinal plants ${ }^{33}$ \\
\hline 33 & Ziziphus elegans & Medicinal plants ${ }^{34}$ \\
\hline 34 & Chassalia curviflora & Medicinal plants ${ }^{35}$ \\
\hline 35 & Ixora javanica & $\begin{array}{l}\text { Medicinal (abdominal pain medication and facilitate labor), } \\
\text { ornamental plant }{ }^{16,27}\end{array}$ \\
\hline 36 & Meyna spinosa & $\begin{array}{l}\text { Medicinal plants, medicines for skin infections, headaches, diabetes, } \\
\text { dysentery, indigestion, stomach worms, liver disorders }{ }^{36}\end{array}$ \\
\hline 37 & Tacca palmata & Febrifuge for children, especially for infants ${ }^{37}$ \\
\hline 38 & Cayratia pedata & $\begin{array}{l}\text { Antioxidants, anticancer, ulcer drugs, herbs for women who were } \\
\text { giving birth }^{38}\end{array}$ \\
\hline 39 & Zingiber officinale & $\begin{array}{l}\text { Reducing hypertension, nausea, stomach cramps, bloating, } \\
\text { headaches }{ }^{22}\end{array}$ \\
\hline
\end{tabular}

Notes: ${ }^{1}$ Puri (2020); ${ }^{2}$ Haryudin (2013); ${ }^{3}$ Nainwal (2019); ${ }^{4}$ Abdelhakim et al. (2017); ${ }^{5}$ Fernandez et al. (2018); ${ }^{6}$ Aziz (2012); ${ }^{7}$ Megawati et al. (2017); ${ }^{8}$ Sahid and Murbawani (2016); ${ }^{9}$ Rosyada et al. (2018); ${ }^{10}$ Samsuar et al. 2018); ${ }^{11}$ Pebriani et al. (2013); ${ }^{12}$ Uji (2002); ${ }^{13}$ Susanti et al. (2018); ${ }^{14} \mathrm{Li}$ et al. (2016); ${ }^{15}$ Nurjanah et al. (2018); ${ }^{16}$ Nursanti et al. (2018); ${ }^{17}$ Yusuf et al. (2016); ${ }^{18}$ Widodo et al. (2018); ${ }^{19}$ Pasaribu and Praptiwi (2014); ${ }^{20}$ Yadav et al. (2012); ${ }^{21}$ Hasan et al. (2016); ${ }^{22} \mathrm{Hadi}$ et al. (2016); ${ }^{23} \mathrm{Kusuma}$ dan Suryani (2017); ${ }^{24}$ Rahayu et al. (2007); ${ }^{25} \mathrm{Samad}$ et al. (2018); ${ }^{26}$ Gauchan et al. (2008); ${ }^{27}$ Haryanti et al. (2015); ${ }^{28}$ Yusufzai et al. (2019); ${ }^{29}$ Sarwanto et al. (2015); ${ }^{30}$ Widhyastini et al (2012); ${ }^{31}$ Purnawati et al. (2014); ${ }^{32}$ Sastrapradja et al. (1979); ${ }^{33}$ Effendi and Lailathy (2016); ${ }^{34}$ Mustika et al. (2014); ${ }^{35}$ Rianti et al. (2019); ${ }^{36}$ Sen and Chakraborthy (2017); ${ }^{37}$ Lamxay et al. (2011); ${ }^{38}$ Rumayati et al. (2014); ${ }^{39}$ Mayangsari et al. (2019).

There were 9 species that had the potential to be developed as ornamental plants (Table 4). Those species belonged to Asteraceae, Nyctaginaceae, and Pteridaceae families. Asteraceae and Nygtaginaceae are well known for their beautiful flowers. However, even though Pteridaceae (fern) do not have flowers, they have diverse leaves and high aesthetic value (Sriastuti et al. 2018; Sukarsa et al. 2011), such as P. latipinna, A. pidatum, and L. flexosum (Table 4).

Furthermore, there were 5 species that had the potential to be utilized as food, namely $D$. alata, N. cordifolia, S. androgynous, P. ensiformis, and L. palmatum (Table 4). S. androgynous is a vegetable and food coloring agent (Juliastuti 2019), while D. alata is an essential species for functional food and food diversification (Yusuf et al. 2016). Meanwhile, N. cordifolia, P. ensiformis, and L. palmatum are the source of vegetables (Astuti et al. 2018).

C. pubescens, E. tenerum, I. timorense, and C. hirta were potentially used as forage (Table 4). C. pubescens was used as a mixed crop or as the secondary plant in the pasture. Several researchers reported that $C$. pubescens improve forage quality, especially protein content (Indriani et al. 2019; Pasaribu and Praptiwi 2014). 
In addition, some herbs were potentially used for cultural ceremonies/handicrafts (4 species) and environmental conservation (3 species) (Table 4). For example, Bougainvillea sp. is widely used as an ornamental plant. However, it is also used in traditional ceremonies (Haryanti et al. 2015). This study shows that KHDTK of Gunung Bromo stores natural resources, not only wood but also undergrowth, as a source of medicinal and ornamental plant, food (fruit, seeds, and leaves), forage, and others.

\section{Conclusions}

There were 39 species of undergrowth from 26 families found under pine stands in KHDTK of Gunung Bromo. The highest IVI was shown by E. tenerum (58.84\%), indicating that this species dominated the undergrowth composition. In addition, C. pubescens showed an IVI of $18.38 \%$, while the other species showed less than $10 \%$. Species diversity index $\left(H^{\prime}\right)$, species richness index $(R)$, and evenness index $(E)$ were $2.35,4.69$, and 0.64 , respectively. This condition indicated that the undergrowth species grown in KHDTK of Gunung Bromo was limited and uneven. It was considered due to inhibiting factors such as allelopathy in pine leaf litter and low light intensity. The study also showed that undergrowth species grown in KHDTK of Gunung Bromo had potential utilization mainly for medicinal and ornamental plants, food sources, and forage.

\section{Acknowledgments}

The authors thank LPPM Universitas Sebelas Maret, for the financial support through Penelitian Unggulan Terapan PNBP UNS 2019. This research is part of the research entitled "Analisis Vegetasi sebagai Data Base dalam Pengelolaan dan Upaya Pengembangan Budidaya Bambu sebagai Identitas Hasil Hutan Bukan Kayu di KHDTK Gunung Bromo Karanganyar".

\section{References}

Abdelhakim, I. A., El-Mokhtar, M. A., El-Baky, A. M. A., and Bishay, D. W. 2017. Chemical Constituents and Antimicrobial Activity of the Leaves of Caryota mitis Lour. (Arecaceae). Journal of Medicinal Plants Studies 5(5): 250-255.

Abdiyani, S. 2008. The Diversity of Understories Medicinal Plants in Dieng Plateau. Jurnal Penelitian Hutan dan Konservasi Alam 1(5): 79-92. DOI: 10.20886/jphka.2008.5.1.79-92

Astuti, F. K., Murningsih, and Jumari. 2018. Diversity of Pteridophyta in Selo Hiking Route of Mount Merbabu National Park, Central Java. Bioma 20(1): 25-30. DOI: 10.14710/bioma.20.1.25-30

Atmanto, W. D., Ndari, H. W., and Danarto, S. 2017. Analysis of Habitat Conditions and Undergrowth Roots in Open Areas and under Casuarina equisetifolia Stands in Lembupurwo Coast, Kebumen. Scripta Biologica 4(3): 147-154. DOI: 10.20884/1.sb.2017.4.3.431

Aziz, S. A. 2012. Cosmos caudatus-Kenikir, King of Vegetable - Functional Vegetables Cultivated Based on Good Cultivation. Faculty of Agriculture, Institute Pertanian Bogor, Bogor.

Destaranti, N., Sulistyani, and Yani, E. 2017. Structure and Undergrowth Vegetation under pine Stands in RPH Kalirsatria and RPH Baturraden Banyumas. Scripta Biologica 4(3): 155-160. DOI: 10.20884/1.sb.2017.4.3.407 
Djufri. 2003. Vegetation Analysis of Spermatophyte in Taman Hutan Raya (Tahura) Seulawah Aceh Besar. Biodiversitas 4(1): 30-34. DOI: 10.13057/biodiv/d040106

Effendi, M., and Lailathy, I. Q. 2016. Pteris ensiformis Burm. F Potency and Taxonomy. Warta Kebun Raya 14(2): 47-53.

Fernandes, A., Maharani, R., and Supartini. 2018. Phytochemical and GC-MS Analysis of Ungu Kucing (Eupatorium odoratum L. F.) Leaf as an Active Pharmaceutical Ingredient. Jurnal Penelitian Ekosistem Dipterokarpa 4(1): 1-8. DOI: 10.20886/jped.2018.4.1.1-8

Gauchan, D. P., Manandhar, D., Shrestha, N., and Suwal, S. K. 2008. Nutrient Analysis of Nephrolepis cordifolia (L.) C. Presl. Kathmandu University Journal of Science, Engineering and Technology 1(5): 68-72. DOI: 10.3126/kuset.v4i1.2885

Hadi, E. E. W., Widyastuti, S. M., and Wahyono. 2016. Diversity and Utilization of Understorey in Agroforestry System of Menoreh Hill, Kulon Progo Regency. Jurnal Manusia dan Lingkungan 23(2): 206-215. DOI: 10.22146/jml.18792

Haryanti, E. S., Diba, F., and Wahdina. 2015. Ethnobotany of Useful Plant to the Society Around KPH Kapuas Hulu (Case study in Tamao Village, District Embaloh Hulu West Kalimantan). Jurnal Hutan Lestari 3(3): 434-445.

Haryudin W. 2013. The Benefit of Pule Pandak (Rauvolfia serpentine) as Medicinal Plant. Warta Penelitian dan Pengembangan Industri 19(3): 21-24.

Hasan, M., Kabir, M. S. H., Ansary, M. A. A, Hasan, M. R., Huda, M. N., Nur, S., Shil, S., Hossen, A., Chakraborty, J., Hasanat, A., and Islam, M. R. 2016. Sedative and Anxiolytic Activities of Methanol Extract of Lygodium palmatum (Bernh.) Sw. Leaves. World Journal of Pharmaceutical Research 5(5): 323-333.

Hilwan, I., Mulyana, D., and Pananjung, W. D. 2013. The Species Diversity of Ground Cover at Sengon Buto (Enterobilium cyclocarpum Griseb.) and Trembesi (Samanea saman Merr.) Plantation in PT Kitadin's Post Mining Land, Embalut, Kutai Kartanagara, East Borneo. Jurnal Silvikultur Tropika 4(1): 6-10.

Ikhsan, Z. H., Nufus, M., Sakya, A. M., and Pertiwi, Y. A. B. 2021. Estimation of Aboveground Biomass and Carbon Stock in a Pine- Mahogany Mixture Stands at Specific Purpose Forest Area of Gunung Bromo, Karanganyar. IOP Conference Series: Earth and Environmental Science 637: 012021. DOI: 10.1088/1755-1315/637/1/012021

Indriani, Hasan, S., Nompo, S., Ako, A., Rusdi, M., Nohong, B., and Khaerani, P. I. 2019. Introduction of Centro Legume (Centrosema pubescens) and Dwarf Napier Grass (Pennisetum purpureum cv. Mott) in Improving Production and Quality of Grassland. International Journal of Scientific and Research Publications 9(3): 234-239. DOI: 10.29322/ijsrp.9.03.2019.p8737

Indriyanto. 2017. Ekologi Hutan, Cetakan 6. Bumi Aksara. Jakarta.

Juliastuti. 2019. The Effectiveness of Katuk Leaves (Sauropus androgynus) on Adequacy of Breastmilk in Breastfeed Mothers at Kuta Baro Community Health Center Aceh Besar. Indonesian Journal for Health Sciences 3(1): 1-5. DOI: 10.24269/ijhs.v3i1.1600

Kunarso, A., and Azwar, F. 2013. Understorey Diversity on Several Plantation Forest Stands in Benakat, South Sumatra. Jurnal Penelitian Hutan Tanaman 10(2): 85-98. DOI: 10.20886/jpht.2013.10.2.85-98

Kusmana, C. 2017. Survey Methods and Interpretation of Vegetation Data. IPB Press. Bogor.

Kusuma, N. A., and Suryani, T. 2017. Exploration of Medicinal Plants in Natural Forest Area Girimanik Setren, Subdistrict Slogohimo, Wonogiri. Proceeding Biology Education 


\section{Conference 14(1): 88-92.}

Lamxay, V., de Boer, H. J., and Björk, L. 2011. Traditions and Plant Use During Pregnancy, Childbirth and Postpartum Recovery by the Kry Ethnic Group in Lao PDR. Journal of Ethnobiology and Ethnomedicine 7: 14. DOI: 10.1186/1746-4269-7-14

Li, Y., Lin, W., Huang, J., Xie, Y., and Ma, W. 2016. Anti-Cancer Effects of Gynostemma pentaphyllum (Thunb.) Makino (Jiaogulan). Chinese Medicine 11: 43. DOI: 10.1186/s13020-016-0114-9

Lubis, A. 2008. Diversity of Piperaceae and Rubiacee in Deleng Lancuk Nature Park, Karo Regency, North Sumatra. Thesis. Sekolah Pascasarjana, Universitas Sumetera Utara, Medan. Mayangsari, A., Indriyanto, Bintoro, A., and Surnayanti, S. 2009. Identification of Medicinal Plants in The Area of KPPH Farmer at Talang Mulya on Wan Abdul Rachman Great Forest Park. Jurnal Sylva Lestari 7(1): 1-9. DOI: 10.23960/js1171-9

Megawati, Sulaeman, S. M., and Pitopang, R. 2017. Diversity of Asteraceae Family at Kalimpa'a Lake in Lore Lindu National Park. Natural Science: Journal of Science and Technology 6(3): 239-253.

Mustika, M., Herawatiningsih, R., and Latifah, S. 2014. Medicinal Plants Diversity in Secondary Forest Area of IUPHHK PT. Kalimantan Satya Kencana, Kabupaten Melawi. Jurnal Hutan Lestari 2(2): 348-356. DOI: 10.26418/jhl.v2i2.7153

Nainwal, P. 2019. Review on Philodendron Species-Plant Seeking for Validation of its Therapeutic Approaches. Journal of Pharmaceutical Sciences and Research 11(5): 20033006.

Nufus, M., Pertiwi, Y. A. B., and Sakya, A. T. 2020. Vegetation Analysis and Tree Species Diversity in KHDTK Gunung Bromo, Karanganyar, Central Java. IOP Conf. Ser.: Earth Environ. Sci. 528: 012010. DOI: 10.1088/1755-1315/528/1/012010

Nurjanah, F., Rokiban, A., and Irawan, E. 2018. Cyperus rotundus Extract as Antibacterial Against Staphylococcus epidermidis and Propionibacterium acnes. Biosfer: Jurnal Tadris Pendidikan Biologi 9(2): 165-175. DOI: 10.24042/biosfer.v9i2.3800

Nurkhotimah, Hikmat, A., and Seytawati, T. 2017. Composition, Structure and Diversity of Species Plant in Dungus Iwul Nature Reserve, Bogor District. Media Konservasi 22(2): 138145. DOI: 10.14203/beritabiologi.v16i2.2648

Nursanti, Novriyanti, and Wulan, C. 2018. Various Types of Potential Drug Plants in Muhammad Sabki Urban Forest, Jambi City. Media Konservasi 23(2): 169-177. DOI: 10.29244/medkon.23.2.169-177

Pasaribu, Y., and Praptiwi, I. I. 2014. Crude Fiber Content of Centrosema pubescens and Capologonium mucunoides in Kampung Wasur. Agricola 4(1): 33-40. DOI: 10.20886/jph. 2008.26.2.166-173

Pebriani, Linda, R., and Mukarlina. 2013. Potential of Mikania micrantha H.B.K Leaf Extract as a Bioherbicide Against Cleome rutidosperma D.C) and Paspalum notatum Flugge. Protobiont 2(2): 32 - 38. DOI: 10/26418/protobiont.v2i2.2735

Puri, A. V. 2020. Artabotrys hexapetalus (L. F.) Bhandari: A Plant with Enormous Biomedical Potential. International Journal of Pharmacy and Pharmaceutical Sciences 12(6): 8-14. DOI: 10.22159/ijpps.2020v12i6.37778

Purnawati, U., Turnip, M., and Lovadi, I. 2014. Eksplorasi Paku-Pakuan (Pteridophyta) di Kawasan Cagar Alam Mandor Kabupaten Landak. Jurnal Protobiont 3(2): 155-165. DOI: 10.26418/protobiont.v3i2.5525 
Purnomo, D. W., Usmadi, D., and Hadiah, J. T. 2018. Impact of Canopy Gap to the Understory Plants Abundance on Stands of Pinus oocarpa Schiede and Agathis alba (Lam) Foxw. Jurnal Ilmu Kehutanan 12: 61-73. DOI: 10.22146/jik.34121

Rahayu, M., Susiarti, S., and Purwanto, Y. 2007. Study of the Utilization of Non-Timber Forest Vegetation by Local Society at PT. Wira Karya Sakti Sungai Tapa Conservation Area-Jambi. Biodiversitas 8(1): 73-78. DOI: 10.13057/biodiv/d080115

Rianti, Y., Purwanti, P., and Wahdina, W. 2019. Potential of Medicinal Plants in Bemban Village in the Protected Forest Area of Gunung Ambawang of Kubu Subdistrict, Kubu Raya Regency. Jurnal Hutan Lestari 7(3): 1470-1477. DOI: 10.26418/jhl.v7i2.37623

Rice, E. L. 1984. Allelopathy-An Overview. In: Cooper-Driver GA, Swain T, Conn EE. (eds) Chemically Mediated Interactions between Plants and Other Organisms. Recent Advances in Phytochemistry. Springer, Boston, MA. DOI: 10.1007/978-1-4757-9658-2_4

Rosyada, A., Anwari, M. S., and Muflihati. 2018. Mangrove Plants Utilization by Society of Bakau Besar Laut Village, Sungai Pinyuh District, Mempawah Regency. Jurnal Hutan Lestari 6 (1): 62-70. DOI: 10.26418/jhl.v6il.23869

Rumayati, Idiawati, N., and Destiarti. L. 2014. Total Phenol Antioxidant and Toxicity Test of Lakum (Cayratia trifolia (L) Domin) Leaf and Stem Extracts. Jurnal Kimia Khatulistiwa 3(3): 30-35.

Sabaruddin, Fitri, S. N. A., and Lestari, L. 2009. Relationship Between the Organic Matter Content with Post Harvest Period of Forest Industrial Plant Acacia mangium Will. Jurnal Tanah Tropika 14(2): 105-110. DOI: 10.5400/jts.2009.v14i2.105-110

Sahid, A. P. N., and Murbawani, E. 2016. The Effect of Cosmos caudatus Leaf Powder on Blood Glucose Level of Streptozotocin-Induced Diabetic Rats. Journal of Nutrition College 5(2): 51-57. DOI: 10.14710/jnc.v5i2.16359

Samad, N. A., Kamal, N. N. S. N. M., Yahaya, N., Yusmaidie Bin Aziz, M., Zain, N. N. M., Yusoff, N. A. M., and Lim, V. 2018. Ethnobotanical, Phytochemical, and Pharmacological Aspects of Melastoma sp. Malaysian Journal of Medicine and Health Sciences 14: 153-163.

Samsuar, Rokiban, A., and Nur, R. 2018. The Ethanol Fraction of Mikania micrantha Kunth Leaves as Anti-Inflammation on Male White Rats with a Wistar Strain. Jurnal Farmasi Lampung 7(1): 51-57. DOI: 10.37090/jfl.v7i1.37

Sarwanto, D., Tuswati, S. E., and Widodo, P. 2015. Diversity and Productivity of Indigenous Forage at Various Levels of Vegetation Density in South Kapur Gombong Mountains. Jurnal Biosfera 32(3): 147-153. DOI: 10.20884/1.mib.2015.32.3.337

Sastrapradja, S., Johar, J. A., Darnadey, D., and Elizabeth, A. W. 1979. Types of Ferns in Indonesia. Lembaga Biologi Nasional-LIPI, Balai Pustaka, Bogor.

Sen, S., and Chakraborty, R. 2017. Meyna spinosa Roxb.: An Unexplored Ethnomedicinal Plant. International Journal of Green Pharmacy 11(3): 332-337. DOI: 10.22377/ijgp.v11i03. 1138

Siappa, H., Hikmat, A., and Karton, A. P. 2016. Vegetation Composition, Distribution Patterns, and Habitat Factors of Ficus magnoliifolia (Nunu Pisang) in Pangale Forest of Toro Village, Central Sulawesi. Buletin Kebun Raya 19(1): 33-46. DOI: 10.14203/bkr.v19i1.117

Solfiyeni, Chairul, and Marpaung, M. 2016. Analysis of Invasive Plants in Anai Valley Nature Reserve, West Sumatra. Proceeding Biology Education Conference 13 (1): 747-747.

Sriastuti, W., Herawatiningsing, R., and Tavita, G. E. 2018. Biodiversity of Potential Ornamental Plants in the Area of IUPHHK-HTI of PT. Bhatara Alam Lestari in Sekabuk Village of Sadaniang Subdistrict in Mempawah Regency. Jurnal Hutan Lestari 6(1): 147-157. DOI: 


\subsection{8/10.26418/jhl.v6i1.24288}

Sukarsa, S., Apriliana, H., and Chasanah, T. 2011. The Diversity of Ornamental Fern Species as an Effort to Conserve Biological Resources of Baturaden Botanical Garden. Biosfera 28(1): 23-31. DOI: 10.20884/1.mib.2011.28.1.257

Susanti, A. D., Wijayanto, N., and Hikmat, A. 2018. Diversity of Medicinal Plants in Repong Damar Krui Agroforestry, Lampung Province. Media Konservasi 23(2): 162-168. DOI: 10.29244/medkon.23.2.162-168

Syahbudin, A., Meinata, A., Arifriana, R., and Wiyono. 2020. Short Communication: The Composition of Undergrowth Vegetation in the Gendol Riverbank, Sleman District, Yogyakarta, Indonesia. Biodiversitas 21(5): 1786-1792. DOI: 10.13057/biodiv/d210503

Tjitrosoedirdjo, S., Setyawati, T., Sunardi, Subiakto, A., Irianto, R. S. B., and Garsetiasih. 2016. Guidelines for Risk Analysis of Invasive Alien Plants (Post Border). FORIS Indonesia. Pusat Penelitian dan Pengembangan Hutan, Kementerian Lingkungan Hidup dan Kehutanan Republik Indonesia.

Uji, T. 2002. Plant Diversity and Their Potential in Mount Halimun and Surrounding Areas in Gunung Halimun National Park. Berita Biologi 6(1): 1-12. DOI: 10.14203/beritabiologi.v6i1.1165

Widhyastini, I. G. A. M., Yuliani, N., and Nurilmala, F. 2012. Weeds Identification and Potential under Superior Teak Nusantara (JUN) Stands in Experimental Garden of University of Nusa Bangsa, Cogreg, Bogor. Jurnal Sains Natural Universitas Nusa Bangsa 2(2): 186-200. DOI: 10.31938/jsn.v2i2.48

Widodo, H., Rohman, A., and Sismindari, S. 2018. Utilizing Fabaceae for Liver Disease Treatment by Traditional Ethnic Healer in Indonesia. Media Litbangkes 29(1): 65-88. DOI: 10.22435/mpk.v29i1.538

Wirakusumah, S. 2003. Dasar-Dasar Ekologi bagi Populasi Dan Komunitas. UI Press. Jakarta.

Yadav, E., Mani, M., Chandra, P., Sachan, N., and Ghosh, A. K. 2012. A Review on Therapeutic Potential of Lygodium flexuosum Linn. Pharmacogn 6(12): 107-114. DOI: 10.4103/09737847.99944

Yusra, Hidayat, M., and Eriawati. 2017. Herbaceous Plant Structure under Pine (Pinus merkusii) Stand at Tahura Pocut Meurah Intan. Proceeding of Biotic National Seminar: 172-179.

Yusuf, M., Arfini, F., and Attahmid, N. F. U. 2016. Formulation of Baruasa Glukomanan-Rich Based of purple yam (Dioscorea alata L.). Jurnal Galung Tropika 5(2): 97-108. DOI: 10.31850/jgt.v5i2.167

Yusufzai, S. K., Khan, M. S., Hanry, E. L., Rafatullah, M., and Elison, B. B. 2019. GC-MS Analysis of Chemical Constituents and In Vitro Activity of the Organic Extracts from the Stem of Bridelia stipularis. Sains Malaysiana 48 (5): 999-1009. DOI: 10.17576/jsm-20194805-08 